\title{
Salar Chinese
}

National Cancer Institute

\section{Source}

National Cancer Institute. Salar Chinese. NCI Thesaurus. Code C158192.

A Chinese person from the Salar ethnic group. 